\title{
Analysis on the Leadership Ability of the Islamic Senior High School Principal in North Sumatera Province-Indonesia
}

\author{
Mesiono \\ Post Graduate in Educational Management, State University Of Medan, Indonesia
}

\begin{abstract}
This study attempted to describe the data analysis on the leadership ability of the Islamic Senior High School Principal in North Sumatera Province. The research respondent are 205 Principal Islamic Senior High School. The data were analyzed by using descriptive analysis. The research finding denotes the highest score variable principal's leadership ability is 189, the lowest are 122, and the mean and standard deviation of 154.49 is 15:41, while the highest score of the ideal 238, the lowest score of 34 is ideal, and the ideal mean score is 136 and the ideal standard deviation is 34 . Data tendency principal's leadership ability is $78.54 \%$ in the moderate category, 21,46\% in the low category. Thus the leadership ability of the Islamic Senior High School Principal in North Sumatera Province has a tendency to moderate category.
\end{abstract}

Keywords: technical capability, the ability of humanity, conceptual abilities.

\subsection{Background}

\section{Introduction}

The principal ideally should have the technical ability, humanist and conceptual. As noted by Robert L. Katz in Schermerhorn characterizes the basic skills of managers in three categories: 1) Technical Capability (Technical Skills) is the ability to use special skills in performing a particular task. 2) Human Ability (Human Skills) is the ability to cooperate with others as well. 3) Conceptual Ability (Conceptual Skills) is the ability to think analytically and solve problems in an integrated manner.

From observation while, it was found that the ability of the Islamic Senior High School Principal in North Sumatera Province, which is less as expected. The was an indicator that the school principal empower teachers to implement the learning process well, smooth and productive, low ability of conseptual indication of lock due to completion of the task and the principal work a predetermined time. The low capabilities of principals, this is evidenced by an unqualified principal in a harmonious relationship with the teachers and the community so that they are less able to engage actively. This is evident from the working climate and the meeting schedule of school committee is tentative. The school development program less productive and less socialized to people.

The above conditions can not be left alone, it is required serious attention and improved efforts of the government through education inservaice such as education and training, mentoring system. However, these efforts have not shown significant change in building principals' leardership capacity.

\subsection{Purpose of Study}

The purpose of this research is to describe the data of Islamic Senior High School leadership capability and determine the level of principal leadership abilities tendency of the school.

\section{Literature Review}

According to Daft that leadership ability that there are three, namely: Conceptual Skills, is the cognitive ability to see the organization as a whole system and the relationship among is parts. Conseptual skill involves the manager's thinking, information processing and planning abilities. Human Skills is the manager's ability to wrok with and through otker people and to work efectively as group member. Human skill ia demonstreted in the way a manager relates to other people, including the ability to motivate, facilitate, coordinate, lead, communicate and resolve conflicts. Technical skills is the understanding of and proficiency in the performance of specific tasks. Tehcnical skills includes mastery of the methods, echniques and equipment involved in specific function such as engineering, manufacturing or finance. ${ }^{1}$

The opinion is in line with Robbins and Coulter, that there are three skills or expertise that must be owned manager or leader is: Technical skills are the job-specific knowladge and techniques needed to proficently perform specific tasks. These skills tend to be more important for lower level managers because they typically are managing employees who wre using tools and teachniques to produce the organization's

${ }^{1}$ Drat, Richard. L. New Era Of Management. (South Western : Cengage Learning, 2010). p.8 
product or service the orgaization's custimers. Human skills, which involve the ability to work well with other people both individually and in a group. Because managers deal directly with people, these skills essential and equally important at all levels of management. Managers with good human skills are able to get the best out of their people. They know to communicate, motivate, lead and inspire enhusiasm and trust. Conceptual skills, are the skill managers use to think and to conceptualize about abstarc and complex situation. Using the skills, managers must see the organization as a whole, understand the relationships among various subinits, and visualize how the organization fits into its broader environment. ${ }^{2}$

According to Paul Hersey and Siswanto Balnchard three abilities or skills that must be possessed by a leader (principal), namely: 1) Technical skills ; ability to use knowledge, methods, procedure, technique and intellect necessary to carry out specific tasks acquired through experience, education and training. 2) human skills ; ability and judgment cultivated with others, including an understanding of the motivation and the application of effective leadership. 3) conceptual skills ; ability to understand the complexities of the entire organization to adapt one's place in the operation.. ${ }^{3}$

Likewise, the opinion stating that Williams was a leader must have three skills: 1) Technical skill is the ability to apply the procedures, techniques, and specialized knowledge needed to finish the job. 2) human skill is the ability to cooperate with others. managers who have the skills to work with the human will effectively within a group, encourage others to express their thoughts and feelings, sensitive to the needs and views of others, as well as an expert listener on good communication. 3) Conceptual skill is the ability to see the organization as a whole, how each part of the enterprise IT can affect others, and how companies can adapt to or influenced by the external environment. ${ }^{4}$

In detail, the indicators used to measure the skills or leadership ability or principal stated by Robbins (2007:14) 1) Conceptual Skills: a. The ability to use information to solve business problems, b. Identify opportunities for innovation, c. Recognizing the problem and implement a solution, d. Selecting critical information from randomized data, e. Understand business uses of technology, f. Understanding the business model of the organization 2) Communication Skills, a. The ability to turn ideas into words and actions, $b$. Credibility among colleagues, friends and subordinates, c. Listening and asking questions, d. Presentation skills; form of conversations, e. Presentation skills; form of written and / or graphic 3) Effectiveness Skills, a.Turut support corporate mission / departmental objectives, b. Focused on consumer, c. A variety of tasks: tasks that many simultaneously, d. Negotiation skills, e. Project Management, f. Reviewing operations and implementing improvements, g. Establishing and maintaining performance standards internally and externally, p. Assign priority to important things and events, i. Time management. 4) Interpersonal Skills, a. Expertise to lead and guide, b. Diverse expertise: working with different people and cultures, c. Networking within the organization, d. Network outside the organization, e. Working in teams: cooperation and commitment. ${ }^{5}$

\section{Method}

The data were collected from 205 respondents, Head of Islamic Senior High Schools (Madrasah Aliyah) in the province of North Sumatera. The respondents filled out questionnaires were prepared based on the indicators of technical ability, the ability of humanist and conceptual abilities. Descriptive data analysis was presented to see the picture of leadership ability of Islamic Senior High School Principals (Madrasah Aliyah) in North Sumatera.

4. The Data Description of the Islamic Senior High School Principal in North Sumatra Province Calculation Summary Descriptive Statistics Research Data can be seen in Table 1.

Table 1. Summary of Results Descriptive Statistics Analysis

\begin{tabular}{|l|l|c|}
\hline \multirow{2}{*}{$\mathrm{N}$} & Valid & 205 \\
\cline { 2 - 3 } & Missing & 0 \\
\hline Mean & 154,49 \\
\hline Median & 155,00 \\
\hline Variance & 166,594 \\
\hline Std. Deviation & 12,907 \\
\hline Minimum & 122 \\
\hline Maximum & 189 \\
\hline Range & 67 \\
\hline Mean ídeal & 136,00 \\
\hline
\end{tabular}

\footnotetext{
${ }^{2}$ Stephen P. Robbins, Coulter, Mary. Management, (New Jersey: Pearson Educational, 2007) p. 42.

${ }^{3}$ Siswanto. Pengantar Manajemen, (Banung : Bumi Aksara, 2005) p. 25

${ }^{4}$ Williams, Chuck. Manajemen, terj. Sabaruddin Napitupuluh. (Jakarta : Salemba Empat, 2001). p. 28 - 29.

${ }^{5}$ Robbins dan Coulter. Manajemen. Edisi Kedelapan/Jilid 1, diterj. Harry Slamet, ( Jakarta : Indeks, 2007 ). p. 12.
} 


\begin{tabular}{|l|c|}
\hline Std. Deviation ídeal & 34 \\
\hline Minimum ídeal & 34 \\
\hline Maximum ídeal & 238 \\
\hline
\end{tabular}

The value of the latent variable statistics Principals Leadership Capabilities after arrangging score 122 then there is the lowest score, highest score 189, 155 with the top quartile median 165.00 , the bottom quartile among 147 so rental quartiles 18 and none of the data are outliers. To clarify seberan data can be presented in the following boxplot in Figure

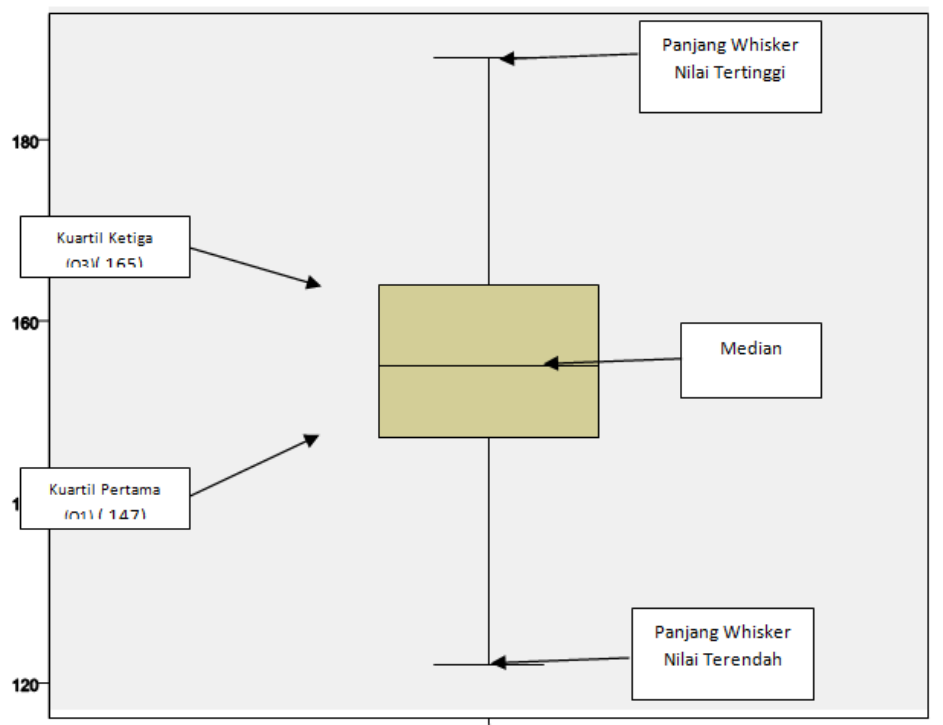

Gambar 4.1 : Boxplot of Leadership capability variable

Based on the picture above boxplot shows that the median line is in the middle of the box and whisker top and bottom have the same length. Thus the variable data about leadership ability of Principals in North Sumatra Province is Symmetrical.

To determine the ability of the leadership of principal at Madrasah Aliyah in North Sumatra province, the mean and standard deviation of the empirical data compared to the ideal standard deviation score of the study. The mean scores of ideal research on these variables can be calculated by the calculation based on the normal curve as follows: Data theoretical minimum score is 34 and the maximum score is 238 . The ideal average value is $1 / 5(34+238)=136$, while the ideal SD (Standard Deviation) is $(238-34)=34$. Based on the results of this calculation the mean ideal variable data of the principal leadership capability is 136 . Subsequently ideal score can be classified into four categories as follows:

Table 2 Levels of Leadership Ability Tendency Variabel

\begin{tabular}{|l|l|l|l|}
\hline Interval & F.Observasi & F.relative & Category \\
\hline$\geq 187$ & - & - & High \\
\hline $136-187$ & 161 & $78,54 \%$ & Median \\
\hline $85-136$ & 44 & $21,46 \%$ & Low \\
\hline$\leq 85$ & - & - & Less \\
\hline Total & 205 & $100 \%$ & \\
\hline
\end{tabular}

Based on the table above, the level of schools principals' ability tendency at aliyah in the province of North Sumatera positioned at the score 34-85 (approximately), 85-136 (low), 136-187 (medium) and 187-238 (high). The results of comparative empirical mean of principals' leadership ability with mean 136 base 154 with four principal categories of leadership skills in middle category. In more detail expressed variable levels tendency of leadership ability at Madrasah Aliyah in North Sumatera there was relatively high. While other respondents were categorized as many as 161 people $(78.54 \%)$. The respondents were categorized at low level 44 people (21.07\%), and no less classified category. Thus it can be said that the head of Madrasah Aliyah in North Sumatra province has a tendency leadership ability in middle category. 


\section{Conclusions}

Distribution of variable data about the leadership capabilities of Principals at Islamic Senior High School (Madrasah Aliyah) in the province of North Sumatera in the form of symmetric, shows that the head of Islamic Senior High School $161(78.54 \%)$ in the medium category, the head of the Islamic Senior High School $44(21.46 \%)$ in the low category. Overall leadership ability of Islamic Senior High School (Madrasah Aliyah) Principals in North Sumatera province tends to medium category.

\section{References}

[1]. Colquit, LePine. Wesson. 2009. Organizational Behavior, Improving Performance and Commitment in the Workplace, New York: McGraw-Hill.

[2]. Drat, Richard. L. 2010. New Era Of Management. South Western : Cengage Learning.

[3]. Lussier, Robert. 2008. Management Fundamentalis Concepts, Application, Skill Development, South-Western: Cengage Learning.

[4]. Luthan S, Fred. 1985. Organizational Behavior. New York: McGraw-Hill Book Company.

[5]. Lee, Deokro. 2006. Toward a Way to Enhance Organizational Effectiveness in the Defense Sector: Associating CVF with DEA, (The Korean Journal Defense Analysis, Vol. XVII, No.1, Spring 2006) h.135-159.

[6]. McShane, Glinow Von. 2007. Organizational Behaviour (Essential). New York. McGraw-Hill.

[7]. Robbins, Coulter M., Management. New York: McGraw-Hill

[8]. Robbins dan Coulter. 2007. Manajemen. Edisi Kedelapan/Jilid 1, diterj. Harry Slamet, Jakarta : Indeks.

[9]. Slocum, Hellriegel. 2009. Principles of Organizational Behavior. South Western: Cengage Learning.

[10]. Stephen P. Robbins, Coulter, Mary. 2007. Management, New Jersey: Pearson Educational.

[11]. Siswanto. 2005. Pengantar Manajemen, Banung: Bumi Aksara.

[12]. Williams, Chuck. 2001. Manajemen, terj. Sabaruddin Napitupuluh. Jakarta : Salemba Empat. 